The religious subjects that have reflections on literature and art and that have influential impacts on Azerbaijan national conscience / R. Mürseloğlu (pp. 206-219)

\title{
Edebiyat ve sanata yansıyan, Azerbaycan milli şuurunda etkili izlenimler bırakan din mevzuları
}

\section{Rüstem MÜRSELOĞLU1}

\begin{abstract}
APA: Mürseloğlu, R. (2019). Edebiyat ve sanata yansıyan, Azerbaycan milli şuurunda etkili izlenimler bırakan din mevzuları. RumeliDE Dil ve Edebiyat Araştırmaları Dergisi, (17), 206-219. DOI: $10.29000 /$ rumelide.656693
\end{abstract}

\section{$\ddot{\mathbf{O} z}$}

\begin{abstract}
Azerbaycan tarihi, Oğuzların, Selçukluların, Moğolların, Arapların, İranlıların, Osmanlıların, Türkiye'nin, Çarlık Rusya, Sovyetler ve günümüz Rusya'sının tarihinden bağımsız olarak incelenemez. Birçok kültürle etkileşim içinde olan bölge halkının özellikle dini konulardaki bakış açıları ve bu bakışın edebiyat ve sanat üzerinden aktarımı ile toplumun milli şuurunda bıraktığı izlenimler araştırmaya değer bir konudur. Din ve dini inançlar toplumun milli ve manevi değerlerini oluşturan, toplumlar arasında var olmasını sağlayan, diğer cemiyetlerden ayıran ve beşerler arasında sorumluluk taşımasını sağlayan bir olgudur. Din ve inanç insana sunduğu değerler sayesinde onu medeniyetler ve kültürler arenasında kendini ifade etme firsatı tanır. Makalede bu olgunun toplum şuuruna sanat ve edebiyat akımıyla nasıl empoze edildiği Azerbaycan usta kalemlerinin eserlerinden örneklerle aktaracağız. Din ile sanat arasındaki çekişmenin edebiyata yansımalarını irdelerken özellikle Sovyet dönemindeki ateist anlayışın etkinliğini gözlemleyeceğiz. Ülkemizde Azerbaycan tiyatrosu ve edebiyatıyla ilgili birçok çalışma bulunsa da kaynak oluşturacak yeterli çalışmaların olduğundan bahsetmemiz düşünülemez. Türkiye'de bu konu üzerine bir araştırma olmadığı için çalışmamızda, Azerbaycan Tiyatrosu'nun belli bir dönemi derinlemesine ele alınmamıştır. Bu anlamda bu çalışmada örnek gösterilen eserler üzerinden çok daha detaylı dramaturjik incelemelere yer veren araştırmaların yapılmasına imkân sağlanacă̆ı amaçlanmıştır.
\end{abstract}

Anahtar kelimeler: Azerbaycan edebiyatı, şiir, din, piyes, sanat.

\section{The religious subjects that have reflections on literature and art and that have influential impacts on Azerbaijan national conscience}

\begin{abstract}
The history of Azerbaijan can not be analyzed independent from the histories of Oghuzs, Seljuks, Mongols, Arabs, Iranians, Ottomons, Turkey, Czarist Russia, USSR and today's Russia. Especially the perspectives of the people in the region related to religion and how the conscience of the nation has been affected by the information which have been transferred through literature and art are two crucial topics worth to think on. Religion and religious believes are the facts that form the national and sentimental values and that enable people to take their parts among the other people and that separate them from the other communities and that enable them to bear responsibility among the other people. Religion and believes enable people to express themselves in the cultural arena. Within the scope of the article we will exemplify how these notions have been imposed on people through literature and art by giving concrete exemples from the texts of writers from Azerbaijan. While
\end{abstract}

$1 \quad$ Dr. Öğr. Üyesi, İstanbul Medeniyet Üniversitesi, Sanat, Tasarım ve Mimarlık Fakültesi, Dil Sahne ve Görüntü Sanatları Bölümü (İstanbul, Türkiye), turkrustam@gmail.com, ORCID ID: oooo-0002-9955-3259 [Makale kaylt tarihi: 05.08.2019-kabul tarihi: 20.12.2019; DOI: 10.29000/rumelide.656693] 
focusing on the tension between art and religion the activities of the atheist mentality of the USSR will also be considered. Despite the fact that there are several researches related to theatre and literature in Azerbaijan, the number of researches are still limited to provide enough source. As there is no specific research on this topic in Turkey not only a specific period from the Azerbaijan theatre has been choosen. The aim of this study is to provide a ground fror futher dramaturgical studies on the texts that have been used as an example in the article.

Keywords: Azerbaijan literature, poem, religion, play, art, national mind.

\section{Giriş}

Azerbaycan, coğrafi konumu açısından Küçük Kafkas'ın dağları üzerinde bulunmaktadır. Bölgenin stratejik değerini artıran en temel unsur, deniz yoluyla Doğu ülkelerine ve Batı-Doğu Avrupa'ya oradan aşağı Volga nehri vasıtasıyla Asya’ya nihayet Hint okyanusuna kısa yollarla ticari ulaşımını sağlamasıdır.

Azerbaycan topraklarını tarihi açıdan önemli kılan bir başka unsur, dünyanın ilk yerleşim meskenlerinden (Azıh mağarası) birine ev sahipliği ediyor olmasıdır. (M.İsmayıl, s, 4-6; G. Kazımov, s, 6-9) Nitekim M.Ö. II ve III. yılında başlayan kavim göçleri zamanla burada Manna, Midiya, Atropatene ve Albaniya gibi büyük medeniyet uygarlıkların kurulmasına neden olmuştur. (G.Geybullayev, s, 12) Kazımov, M. İsmayıl, Geybullayev, gibi tarih araştırmacı ve dilbilimcilerinin belirttiği üzere Azerbaycan dilinin esas temelini Kafkas’a göç etmiş Türk kabileleri oluşturur.

Pek çok kavimler arasında etnik aynılıkla birlikte dini inanç yönünden de benzerlik taşıdıkları görülmektedir. Arkeolojik kazıntılarda kurgan mezarlarından çıan at iskeletleri ve taşlar üzerindeki ay ylldız tasvirlerini buna örnek olarak göstere biliriz.

Sakalar'dan sonra Azerbaycan (kuzey) ve çevresinde hükümranlığını ilan eden Alban şahlığı Hıristiyanlıktan önce, güneşe, aya, yıldızlara ve mahiyetini bilmedikleri, korktukları şeylere tapıyorlardı. (N. Babayev, R. Nerimanov, s, 62 ) İlk defa Albanların eski inançları hakkında bilgi veren Strabon, buradaki tanrıların ismini Yunanca zikretmiştir. Ayrıca aynı tarihlerde bu tür inançların İran coğrafyasında varlığından bahsedilir. (Z. Bünyadov, Y.B. Yusifov s, 169)

Azerbaycan, bazı kaynaklarda Mecusilik yani Zerdüşt inanç temeli olan bir coğrafyanın "od" anlamındaki "azer" ve "muhafiz" anlamındaki "baygan" kelimelerini birleşimiyle "Azerbaygan", "ateşin muhafizı" anlamını taşıyan daha sonralar Azerbaycan olarak tanımlanan bölgenin ismidir. (A. Ferhat s, 254-257)

\section{Dünya Edebiyatından Dini Mevzulara Genel Bir Bakış}

Ünlü Rus şairi Puşkin’in “Gavriliada” eseri Voltaire’nin eserine ruhen yakındır. Eserde Hz. İsa’nın, Hz. Meryem'den olmasını yani onun karnına konulması alaylı bir şekilde aktarılmaktadır. XIX-XX. yüzyılın Rus edebiyatında ve sanatında dini konuları ifşa etmek, aşağılamak önemli ve öncelikli bir görev olarak tanımlanmaktaydı. Sözde "hümanizm ve demokratizm" eylemli realist Rus sanat ve edebiyatına hizmet eden Saltıkov-Şedrin, M. Gorki, Demyan-Bednı, V. Mayakovski gibi isimler dine karşı mücadelede önde gelen ünlülerden sayılırdı.

Rus ressamlarının yaratıcılığında provaslav din görevlilerin yaşamı ve faaliyetleri sözde realist biçimde tabloya yansıtılmıştır. V. Perov, İ. Repin'in bu yöndeki hizmetini hususiyle kaydetmek gerekir. Din 
The religious subjects that have reflections on literature and art and that have influential impacts on Azerbaijan national conscience / R. Mürseloğlu (pp. 206-219)

görevlilerini küçük düşürecek mizahta boyanan resimlere Perov’un "Paska günü köyde haç yürüyüşü”, "Köyde Moiza”, "Manastırda Eğlence” isimli çalışmalarını örnek göstermek mümkündür. Rusya'da din görevlilerini daha doğrusu dini hedef alan çalışmaların kaynağı tabii ki çok daha eskiye dayanmaktadır. Bu sadece Rusya'da değil saldırganlık aslında Batı kaynaklı çalışmaların ürünüdür. Örneğin kadim Roma dönemi sanatında dine karşı muhalif kalkınma oldukça güçlüdür. Bu mücadelenin sanattaki önemli yansımaları Titus Lukretius Carus'un "Her şeyin tabiatı hakkında" (Latince: De rerum natura) adlı felsefi ateist eserinde ve Lukianos'un "Dialoklar" silsilesinden olan satirik eserlerinde de görmekteyiz. Bunlardan birincisi Demokrit'in ve Epikur'un materyalist felsefesine isnat ederek dünyanın kendiliğinden var olduğunu ve Allah'ın varlığına "efsane" (rivayet) olarak hesap eder. Lukretsin'in Batı Avrupa ateizmine "Reformasyon" dönemi ateistlerine büyük etkisi olmuştur. Lukianos ise, "Tanrıların Sohbeti”, "Ölüler Saltanatından Sohbetler", "Tanrılar Meclisi” vb. hararetli mükâlemelerinde bir çok ateist fikirleri savunulmaktadır.

F. Engels, "Hristiyanlar hakkındaki ilk en iyi kaynaklarımızdan biri Samsatlı Lukianos, kadim klasik devrin bir Voltaire'idir. O, dini itikatların hepsine şüphe ile yanaşmış, Hristiyanlara da başka dini inançlara sahip kişilere de aynı çizgide yaklaşım sergilemiş” olduğunu savunur. (K. Marks ve F. Engels, s, 469) K. Marks ise Lukianos'un dine karşı mücadelesindeki hizmetlerden bahsederek şöyle bir açıklama getiriyor "Artık bir defa Eshil'in (Eshillos) “Zincire Vurulmuş Prometheus" eserinde ölümcül biçimde yaralanmış olan Yunan Tanrıları bu defada komik biçimde Lukianos'un sohbetlerinde ölmeye mahkum kaldılar" (K. Marks ve F. Engels, s, 53) Marks ve F. Engels felsefesiyle kurulan Rus Sovyet sistemi yıllarca din kavramını bu anlayışla empoze etmiştir ve dönemin edebiyat ve sanat alanındaki çalışmaları da etkilemiştir.

Reformasyon döneminin birçok eserinde din mevzuları, Tanrılara karşı mücadele edilmesi, din temsilcilerini riyakarlıkla itham ve ifşa eylemi, açıkça seslendirilmekteydi. İtalyan yazar G. Boccaccio'nun "Dekameron” öyküleri, Holandalı D. Erasmus Roterodamus’un "Deliliğe Övgü” kitabı, Fransız yazar F. Rabelais'in "Gargantua” ve "Pantagruel” satirik romanı, İngiliz yazar J. Milton'un "Kayıp Cennet” gibi birçok satirik sahne eserleri bunlara birer örnektir.

Avrupa'da Rönesans döneminde dini konuların ifşası daha da hızlanmıştır. Fransız yazar Diderot'un "Dindar Kadın”, Voltaire’nin “Kandid”, “Orleai Bakiresi” eserleri dine karşı açıkça saldıran özellikleriyle öne çıkan eserlerdendir. Unutulmamalıdır ki sonrası Aydınlanma düşüncesiyle birlikte aklın merkezi konumu geçmesi, kilisenin otoritesinin bu bağlamda gerilemesi bu düşünceleri kaçınılmaz olarak etkilemiştir.

\section{Din mevzularının Azerbaycan edebiyat ve sanatına yansımaları}

Batı'da ve Rusya'da olduğu gibi Doğu halklarının ve konumuzla ilgili ele aldığımız Azerbaycan edebiyat ve sanatının da bu hususta çalışmaları çok daha eskiye dayanmaktadır. Toplumsal şuurun uyanışı adıyla lanse edilen bu yönelimin edebiyat ve sanatta ki yansımalarını daha XII. yüzyılın yazarlarının kaleminden gözlemlemekteyiz. Hakani, Nizami döneminden başlayarak İslam'a karşı zaman zaman sert tepkilerin konulduğu müşahede edilmektedir. Nizami Gencevi şiirlerinde İslam dininin Muhammet ümmetine aşıladığı tahammül ve teslimiyet fikri eleştirilirken insan yetenekleri ve cesareti övgüyle aktarılmaktadır.

Sufilik, daha doğrusu onun panteizm felsefesine istinat eden ve kendi dönemiyle ilgili gelişmekte olan çalışmaları Azerbaycan şiirine doğrudan etkisini göstermiştir. Panteist görüşlü sufiler her ne kadar 
Allah’ın varlığını inkâr etmeseler de onun ulaşılmaz ve gözle görünmez olduğunu kabul etmiyorlardı. Onlar Allah’ın varlığını, tezahürünü, maddi alemde görmekteydiler. Dünyanın, doğanın güzelliğini, dünya nimetlerini İslam'ın dünya hakkında vadettiklerinden daha üstün görmekteydiler. XII. yüzyılın ünlü şairi Hakani Şirvani gazellerinin birinde şöyle ifade etmektedir.

Sen bize azatlıktan vurma dem, dil dökme hiç,

Çünkü biz cennet, cehennem korkusundan azadız,

Kabe'den, zemzem suyundan açma söz, Hakani'ye

Bade ver, biz Kabe’den, zemzem suyundan azadız. (Bkz. M. Memmedov, s. 98)

Sufizm’in bir başka gelişmiş kolu Hurufiliğin kurucusu olan Fazlullah Naimi’dir. Bu tarikatta panteizme isnat eder. Yerin ve göklerin varlığını, güneşin ışığını, insanın içindeki aşkını Allah’ın tecellisi olarak görmekteydiler. Çünkü baharın güzelliği, toprağın nimetleri, çiçeklerin kokusu, bir reyhan kokusu, yaratanı temsil eder düşüncesini İ. Nesimi şiirlerinde daha açık ifade edilmektedir.

Eğer ki, sünbülü nergiz beyani-kenti kenz eyler,

Gaçan bülhem ezel bilsin işaratın bu esrarın,

Bugün ger alemi-geybin vücudun görmek istersin

Riyahın uş beyan eyler zühurun çerhi-seyyarın.

Sevdiği kadına yazdığı şiirde ise,

Vermez seni bin cenneti, bin hure Nesimi,

Sen aşige hem cennetü hem huri cahansın. (M. Memmedov, s. 99)

ifadelerini kullanmıştır. Burada insanı ve özellikle kadın haklarını İslam'da kadına gösterilen sınırlamalardan arındırarak kadının aşk ile anlatmayı dile getirmektedir.

İnsan aşkını dile getiren, özgürlük konularına XVI. yüzyılın ünlü şairi Füzuli’nin yaratıcıllğında da rastlamaktayız. Füzuli’nin dünya görüşü, felsefi görüşleri “deist” olarak tanımlanmaktadır. Deizme mensup olan bütün düşünürler gibi o da Allah’ın varlığını mutlak şekilde inkar etmemektedir. Yalnız Allah tarafından yaratılan dünyanın kendi kuralları temelinde görülen ve mevcudiyetinin mümkün olduğuna inanmaktadır. Bütün deistler gibi Füzuli de İslam dininden farklı olarak materyalist fikirler de öne sürebilmektedir. Çünkü Marksizm kurucularının kaydettiği gibi "deizm her halde materyalist için dinden kurtulmanın en uygun ve kolay yoludur”. (K. Marks, F. Engels, s, 144) Füzuli bu usulden faydalanarak, zihniyeti, İslam fanatizmini, cehaleti ifşa etmektedir. Şairin bu yönde eleştirel yaklaşımı bazı şiirlerine yansımaktadır. Sözde kör itikadı, ibadeti, vaizleri eleştirel açıdan gazelden açıkça anlaşlmaktadır.

Gönül seccadeye basma ayak, tesbihe el vurma,

Namaz ehline uyma, onlar ile durma, oturma!

Eğilip secdeye, salma feragat tacını başdan,

Vizudan su sepip, rahet uykusun gözden uçurma,

Sakın pamal olursan buraya tek, mescide girme,

Ve ger naçar girsen, onda minber kimi çok durma!

Müezzin nalesini alma kulağa, düşme teşvişe, 
The religious subjects that have reflections on literature and art and that have influential impacts on Azerbaijan national conscience / R. Mürseloğlu (pp. 206-219)

Cehennem kapısın açturma, vaizden haber sorma!

Cemaat izdihamı mescidi salmış küduretler,

Küduretü zere, lütfet, bir küduret sen hem arturma! (M. Memmedov, s. 105)

Dine karşı itiraz ve muhalefet, Azerbaycan edebiyatında sürekli olmuştur. XVIII. yüzyılda Saib Tebrizi din, tarikat ayrılığından doğan facialara, din görevlilerin sözde tefrikalarına karşı çıkmış, insanlar arasındaki aşkı, kardeşliği tebliğ etmiştir. Vagif'in çalışmalarında da doğanın güzelliklerine, insanın zekasına bir övgü vardır. M. Ş. Vazeh, S. A. Şirvani ve daha birçok Azerbaycan yazarlarının yaratıcılıklarında bu mevzuda ciddi çalışmalar ortaya konulmuştur.

Azerbaycan drama sanatının kurucusu M. F. Ahundov felsefi eserlerinde olduğu gibi estetik yaratıcılığında da (ünlü komedi oyunlarında) dini mevzuları eleştirilere geniş yer vermekteydi. Birçok kaynaklarda Ahundov'un mücadeleci ve gerçek bir ateist olduğu yönünde görüşler vardır. İlk komedi oyunu "Hikayeti- Molla İbrahim Halil Kimyager" eserinde dolandırıcı kimyageri, ikinci komedisi "Hikayeti Mösyö Jordan ve Derviş Mestelişah" eserinde ise sihir, cin ve şeytan inancını gülünç bir biçimde hedef almaktadır. (D. Memmedova, s, 2)

“Molla İbrahim Halil...” oyununun ilk perdesinde olaylar Nuha şehrinde kuyumcu Hacı Kerim’in evinde cereyan etmektedir. Onun hemşerileri Doktor Ağa Zaman, Molla Selman, Tüccar Meşedi Cabbar, Esnaf Sefer Bey, istişare etmek için bir aradadırlar. Haçmaz bölgesinden gelen Şeyh Salah, onlara molla İbrahim Halil’in Haçmaz dağındaki mis mamulünü kendi icadı olan iksirle gümüşe çevirdiğini anlatmaktadır. Para hırsı ve nefis onların gözünü adeta kör etmiştir. Hemen Haçmaz’a gitmeye karar verirler. Onların hemşerisi şair Hacı Nuri "iksirin alemde gerçekliği yoktur" diye onları bu fikirlerinden vaz geçirmek istese de onların sihre, fala, inanışları hele molla İbrahim Halil gibi ruhani kişiliğe gösterdikleri itimat ve tabii ki nefislerine yenik düşmeleri onlara söylenenleri kulak ardı etmelerine ve Haçmaz'a gitmelerine neden olur.

M .F. Ahundov, eserde Nuhalılar'ı İbrahim Halil'in kerametine inanan "Allahüekber", "Suphanallah" diyerek bütün bu kerametin Allah’tan geldiğini ve onun hüneri olduğuna inanan bir toplum olduğu gibi göstermektedir. Piyesin sonunda dolandırıcılığın deşifre edilmesiyle hem inananları, hem de dolandırıcıyı sert bir dille eleştirerek bu rezaletin gerçek yaşamdan kesitler olduğu ve kaynağının çok daha derin dini kökleri olduğu vurgulanmıştır.

Aslında M. F. Ahundov İslami ilimler tahsilini Tebriz, Nuha ve Gence'de almış, Fars dili ve Arapçayı çok iyi derecede öğrenmiş bir yazar, felsefeci, eğitimci ve reformcu olarak tanınmaktadır. Bütün bunlara rağmen sadece İslam’ değil, bütün dinlere karşı olumsuz bir görüşü olmuştur. Din tanımına farklı bir yaklaşım sergileyen yazar; "Her hangi bir din, üç temel üzerinde şekillenmektedir. İtikat, ibadet ve ahlak. Her dinin yaratılışında asıl ve esas alınan üçüncüdür. İtikat ve ibadet asıl olana teferruattır.” (M. F. Ahundov, s, 129) ifadesini bazı gerekçelerle savunmaktadır. Şuursuz ibadetin zamanla alışkanlığa dönüştüğünü söyleyen yazar, okuduğu duanın farkına varmadan ibadet eden ve böylece borçlarını yerine getirdiklerine inananlar olduğunu vurgulamaktadır. Ahlak konusuna gelince de o her türlü riyakarlık ve yalana, kötü ameller işlemeye yönelen din temsilcilerini hedef alarak ağır bir üslupta eleştirmektedir. Özellikle toplumsal ahlak ve din hususlarının altı fazlasıyla çizilmiştir.

Aynı çizgide devam eden yazarlardan biri de Celil Memmedguluzâde'dir. (Bkz. D. Memmedova s, 106) 1909 yılında yazmış olduğu "Ölüler” komedisi ilk 1916 yllında Bakü’de oynanmıştır. Eserde dinin topluma vermiş olduğu zararlarını gündemine alan yazar, halkın şuurunda etkileyici izlenimler 
bırakmıştır. “Ölüler” eserinin karakter ve tipleri yaşarken ölmüş birileri gibi gösterilmektedir. Onlar sanki histen, idrakten, maneviyattan yoksundurlar. Bunların tamamı Allah korkusuyla yer değiştirmiştir. Onların düşünmeye, tahlil etmeye, şüphelenmeye hakları yoktur. Allah ve peygamber, din ve şeriat adına ne söylense onlar inanmalılar ve inanıyorlar. Şeyh, molla, vaiz olan her kişinin yaptığı ve söylediği onlar için mukaddes bir hakikattir. Bu nedenle Şeyh Nesrullah’ın, ölenleri diriltebileceğine hemen inanırlar. İnandırmak için Şeyh Nesrullah hiçbir eziyete katlanmamakta ve herhangi bir mucize ortaya koymamaktadır. Aslında Şeyh Nesrullah güçlü ve akıllı biri de değil. Onun gücü, saf, temiz insanların cahilliğindedir. Yazarın, Şeyh Nesrullah'ı bu insanlara göndermekte ki maksadı bu şehrin, genel anlamda bu bölgenin toplumundaki sosyal rezaleti, cehaleti, zihniyet ve ahlak bozukluğunu göstermektir. Bütün bu yöntemleri kullanırken yazar, eserin ikinci perdesinde topluma Şeyh Nesrullah'ın Arapça ve Farsça söylediği iki fikri yürütülmektedir. İlki; bu dünya hiçtir, sende ahiret aşkı varsa bu dünyada güzel olarak gördüğün her şeyi kalbinden söküp atmalısın. İkincisi; elinizden geldiğince fazla nikah ve siğe (muta) yapmalısınız çünkü bunlar size cennet kapılarını açar. Yediği günde tek hurma olduğunu söyleyen Şeyh, gece el ayak çekildikten sonra odasına dünyanın en lezzetli yemeklerini istemekle beraber geceyi genç kızlarla geçirmeği talep eder. Hatta bu kız çocukları Şeyh'in şehvetini dindirmezlerse cehennemde nasıl bir azaba uğrayacaklarıyla korkutmaktadır. Yazar, toplumun varını, malını, aklını, namusunu elinden alan, bu “İsfahan Kabadayısı” Şeyh’in, önünde tir tir titretenin cehennem korkusu olduğunu öne çıkarmaktadır. Dolayısıyla yaşanan bu olayı dramatik biçimde ve dini hedef gösterecek algılama yöntemiyle ortaya koymuştur.

Sadece drama sanatında değil satirik şiirlerde de toplumun cehaleti dönemin usta kalemleri tarafından ciddi biçimde ele alınmaktaydı. Bu anlamda, M. E. Sabir'in satirik şiirlerinde dönemin yolsuzlukları, halkın ağır yaşam koşulları, memleketin gelişmesine engel olan unsurlar sert bir üslupta eleştirilmektedir. Şairin görüşüne göre zulmün, istibdadın, gericiliğin sebebi dönemin usul- idaresinde olsa da halkın acı kaderi yaşamasında din temsilcilerinin rolü az değildir.

Cehaletin hükmettiği bir cemiyette, veliler de kendi evlatlarının dünyevi mekteplerde okumasına müsaade etmiyorlardı. Çocukların okumasını talep edenlere de "okutmayacağım... ısrar etmekten vaz geçin” cevabında bulunuyorlardı. M. E. Sabirin “Okutmuram, El Çekin!” şiirindeki tenkit, aslında dönemin din temsilcilerinin insanları bu yönde kışkırtmalarına yönelik olduğuyla bilinmektedir.

Eylemerem rehm onun gözden akan yaşına,

Baksın özünden büyük öz koçu kardeşine,

Ölse de vermem rıza şapka koya başına,

Kafir ola bir nefer, okutmuram el çekin!

Eylemeyin dengeser, okutmuram, el çekin!

Koysanız öz oğlumu ben salım öz halime,

Sanatımı öğretip, uydurum ehvalime,

Dün bu okutmak sözün arz eledim alime,

Söyledi : "haza kefer...", okutmuram el çekin!

Eylemeyin dengeser, okutmuram, el çekin!

Besdi, cehennem olun, bunca ki, aldatmısız,

İndi beş ildir tamam dinime el katmısız, 
The religious subjects that have reflections on literature and art and that have influential impacts on Azerbaijan national conscience / R. Mürseloğlu (pp. 206-219)

Sevgili evladımı kafire benzetmisiz,
Duydum işin serbeser, okutmuram el çekin!
Eylemeyin dengeser, okutmuram, el çekin!

Fikrimi vermem ebes siz kimi nadanlara,

Sevk edesiz oğlumu bir para hedyanlara,

Çünkü hıanetçisiz cümle Müslümanlara,

Menzilınizdir seger, okutmuram, el çekin!

Eylemeyin dengeser, okutmuram, el çekin!

Dine zarardır, zarar, okutmuram, el çekin! ( M. E. Sabir, s. 193-194)

Şiirden de anlaşıldığı üzere din, insanların tahsil ve ilim görmesine mani bir unsur gibi aktarılmıştır. Eksiklikler, kötülük ve fakirlik içinde bocalayan cemiyeti ışıklı sabahlara çıkartacak olan zekâ sahibi aydınlar olacağını tebliğ eden şair, dönemin bazı "intiligent” (Batı'da veya Rusya'da tahsil görüp gelenler) kişileri de halka tepeden baktığı için şiddetle kınamaktadır. "Türkü okumak bize şayan değil" söyleyen "intiligentleri” şair gülüş hedefine koymuştur.

M. E. Sabir'in satirik şiirlerinden konuşulduğunda C. Memmedguluzâde'nin "Sizi deyip gelmişim ey benim Müslüman bacı ve kardeşlerim!" mukaddimesiyle ışı yüzü gören "Molla Nesreddin” dergisini unutmamak gerekir. "Molla Nesreddin" dergisi C. Memmedguluzâde ve yardımcısı Ömer Faik Nemanzade öncülüğünde 1906-1931 yıllar arasında Türkçe yayımlanan Azerbaycan edebiyatının ilk mizah dergisidir. İlk sayısı o7 Nisan 1906 yılında Tiflis'te yayımlanan dergi bazı dönemlerde yayına ara verse de yirmi beş yılda yedi yüz yetmiş altı sayısıyla basın ve edebiyat alanında etkin olmuştur. Tiflis'te üç yüz yetmiş, Tebriz'de sekiz, Bakü'de üç yüz doksan sekiz sayısı yayınlanmıştır.(F. Hüseyinov, s, 14) Dergi her ne kadar Sabir gibi usta kalemi kadrosunda tutmuşsa da Sabir için de bu dergide yazmak önemli bir firsat olmuştur.

Bolşevik devriminin hemen ardından kurulan Sovyet yönetiminde dram eserlerinin mevzularında dinin ifşası önemini korumuştur. 1920'li ylların mahsulü olan piyeslerin çoğunda özellikle "Türk tenkit ve tebliğ tiyatrosu" sahnesinde oynanan küçük oyunların ekseriyeti din ve din tebliğcilerin kritiği üzerinedir. Tiyatronun açllış gününde oynanan Süleyman Sani Ahundov'un "Çarkı-Felek" oyununda ihtiyar Piri-Fani imgesiyle dinin aşıladığı sabır ve tevekkül zihniyeti, kadere boyun eğmek, kısmete kani olmak fikri eleştirilmiş, özgürlük mücadelesi, sınıflar arası mücadele yolu hakkın yolu olarak nitelendirilmiştir. Yine adı geçen yazarın "Şahsenem ve Gülperi" oyununda kadınların tiyatroya gitmelerinin büyük bir günah olduğunu söyleyen Molla Kasım, yürütmekte olduğu ilginç fikirleriyle mantıksız biri olarak gösterilmiş ve komik duruma düşürülmüştür. Bu yöndeki çalışmalarda oyuncuların katkısı da az olmamıştır. Mirzaağa Aliyev, Hacağa Abbasov, Ahmet Gamerlinski de drama sanatıyla uğraşmış, "Orada öyle burada böyle", "Sabir'in mahkemesi”, "Molla Zaman" gibi küçük piyeslerde din görevlilerin sahtekarlıklarını mevzu edinmişlerdir.

1920-1930'lu yıllarda din konusunda daha etkin olan iki isim öne çıkmaktadır. Hüseyin Cavid ve Cafer Cabbarlı. Kendi tarzlarıyla yazan ve bu yönde öne çıkan isimlerden sayılırlar. "Şeyh Senan" ve "İblis" faciasını daha devrim öncesi yazan H. Cavid'in bu iki eseri, Sovyet döneminde basılmış ve sahnelenmiştir. Bu eserlerin mevzusu sadece din ve dine münasebetle sınırlı değildir. İnsan ve yaşam hakkında, beşeriyetin talihi hakkında yazarın felsefi düşüncelerini, hayallerini ifade eden eser olarak kabul görse de farklı dinlere karşı görüşleri ortaya koyması, konumuzla ilgili olduğundan incelenmeğe 
değerdir. Bu iki eser, devrimin ilk on yllında Azerbaycan tiyatrosunun repertuarında en fazla yer alan oyun eserleri olarak bilinmektedir. "İblis" faciasının maksadı sadece İblisin "mevhum” bir varlık olarak din temsilcileri tarafından uydurulduğunu ispat etmek değil, bu kendiliğinden ispata yeter. Güya burada ki asıl amaç, daha geniş ve karmaşıklı̆̆ı ortaya koymaktır. H. Cavid kendi yöntemiyle topluma verdiği mesajda beşeriyetin asırlar boyu çektiği azapların ve karşlaştı̆̆ı zorlukların, felaketlerin sebebi göklerde olmadığını, cemiyetin kendinde, amellerinde ve ilişkilerinden kaynaklandığına dikkat çekmektedir. İnam, ve gerçeklik namına yaratılmış dinler, onların uydurmuş olduğu Tanrılar, kendileri beşeriyet için bir felaket, musibet ve trajik bir aldanmaktır düşüncesini sergilemektedir. Bu bakımdan Cavid dinlerle karşılaşmada ithamcı ve isyancı yaklaşımı "İblis" imgesinde yansımaktadır. Bu imgeyi anlamak için onun dini ve tarihi kaynağı, edebi ve genetik kökleri hakkında ilave etmek gerekir. İblis hakkındaki mitoloji, Kur'an dan önce Tevrat ve İncil'de de vardır. Bu imge kadim toplumların mitolojisinde şüpheci güç, gerçekleri arayan biri gibi aktarılmıştır. Dünya edebiyatı ve dramaturjisi sıkça İblis imgesinden istifade etmiş̧ir. Bu imge çeşitli ilişkileriyle canlandırılmıştır. Ortaçağ drama sanatında "Mistery ve Miracle" (Gizem ve Mucize) oyunlarında, Dante'nin "La Divina Commedia" (İlahi Komedya) eserinde İblis şer kuvvedir. Aynı zamanda İncil'de ve Kur'an'da tasvir edilen günahkâr, bedhah (kötü kalpli) melektir. Yalnız L. Byron'un "Kabil" dramında yahut Lermontov'un "Demon” (Şeytan) eserinde müspet bir kahramandır ve Prometey’i anımsatan, sıkıntılara katlanan, isyankâr bir güçtür. Hakikat ve adalet arayıcısıdır. Dini kitaplar, o cümleden Kur'an bile İblisi "şer kuvve" gibi aktarmış olsa da H. Cavid eserinde bu tanım, tamamen farklı biçimde seyirciye aktarmaktadır. Bu "imge" görüntü olarak dini kitaplarda aktarıldığı gibi kötülüğü temsil etse de fitne, felaket, kan, muharebe ve ölümle kuşatılmıştır. Ve bunlardan haz almaktadır. Fakat mahiyet bakımından, içerik açısından bu haz almanın sebebi farklıdır. Bunların asil sebebi, insanın vehim olanı gerçek algılamasıdır. İblis, onun adı üzerinden yapılan ve ona yazılanları görmekte ve göstermektedir ki, bütün bu faciaların, bütün bu bedbahtlıkların temel sebebi insanların bir yanılgı ve aldanış içinde olmasındandır. Yazarın kalemiyle İblis göstermektedir ki, adil olarak bilinen Tanrı hiç de adaletli değil, kudretli değildir. O Allah'ın hiç de Rahim ve Rahman olmadığını, dünyada yaşanan felaketlere, muharebelere, çatışmalara müdahale edemediğinden adil ve affedici birinin kendi yarattıklarını zulüm içinde yaşatmayacağıyla kıyaslamaktadır. Dünyadaki adaletsizliğin, istismarın, insanlar arasındaki eşitsizliğin, zengin fakir ayrılığı ve en önemlisi din ayrılığı niçindir? Allah adil ise neden herkesi aynı ölçüde mutlu kılmamaktadır? H. Cavid faciasındaki İblis, hem oyundaki karakterlerin hem de seyircilerin önüne bu soruyu koymaktadır. Yazar, Allah inancını eleştirmekle beraber eserdeki İblis kendi okuyucu ve seyircilerine hatırlatmaktadır ki, asıl iblisler hayattadırlar. Bunlar yeryüzündeki adaletsizliğe sebep olanlar, fitne üretenlerdir. İblis, "kan içen kinli krallar", "çılgın kabadayılar" ayrımcı din temsilcileridir. Nihayet yazar, İblisin son monoloğunu şu şekilde aktarmaktadır.

Bensiz de emin ol, size rehberlik eden var,

Kan içen, ateş püsküren, kinli krallar,

Şahlar, ulu hakanlar, o çılgın kabadayılar,

Altın ve kadın düşkünü divane bebekler

Bin hile kuran tilki siyasiler, o her an

Mezhep çıkaran, yol ayıran hadimi-edyan;

Onlar, evet, onlar sizi çiğnetmeye kafi,

Kafi, sizi kahretmeye, mahvetmeye kafi...

Ben terk ediyorum sizleri el'an , neme lazım!

Hiçten gelerek, hiçliğe olmaktayım azim, 
The religious subjects that have reflections on literature and art and that have influential impacts on Azerbaijan national conscience / R. Mürseloğlu (pp. 206-219)

\author{
İblis nedir? \\ Cümle hiyanetlere bais... \\ Ya her kese hain olan insan nedir? \\ -İblis...
}

Eserde İblis imgesi doğaüstü bir varlıktan doğal bir varlığa, iblislikten insanlığa çevrilmektedir. Bu faciayı üretenler içinde "hadimi-edyan" yani din temsilcileri, tarikatçllar da vardır ki onlara ayrı bir parantez açılmıştır. Piyesin son perdesinde kaçaklar bir gurup kişileri yakalar ve getirirler. Bunlardan biri İslam Şeyhidir ve İran'da İngilizlere hizmet edenlerdendir. Diğeri Yahudi hahamıdır. Bu "İblis" de Arabistan'da Fransız casusudur. Üçüncüsü de Ermeni keşişidir. Dolayısıyla İblis, aslında insanların içinde olduğunun altı çizilmekle beraber özellikle din temsilcilerinin eserde keskin bir dille eleştirildiği dikkat çekmektedir.

H.Cavid'in "Şeyh Senan” eserinde dinlerin, özellikle İslam'ın tenkit edilmesine hususi yer verilmiştir. Eserdeki kahraman Şeyh Senan, tezatlı bir hayat yolu geçirmektedir. İlk perdede onu şüpheler içerisinde yaşadığını görürüz. Peygamberin Miraç hadisesine şüpheyle yaklaşımı, Şeyh Mervan ve Şeyh Naim gibilerine göre küfre girse de, Şeyh Kebir bu şüphenin hakikat aşkından doğduğunu düşünmektedir.

Şüphedir her hakikatin anası,
Şüphedir ehli-hikmetin babası
Şüphe artarsa, hem yeğin artar
Marifet nuru şüpheden parlar
Şüphe etmekte haklıdır insan...

Şüphecilik Şeyh Senan'ın sadece karakter çizgisi değil aynı zamanda onun dünya görüşüdür. Şeyh Kebir'in ölümünden sonra, mürşidi İslam olduktan sonra da İslam'ın hak ve adalet getirdiğine şüpheyle yaklaşır. Yalnız ikinci perdede şeyhler sefere çıktıklarında Şeyh Senan aynı zamanda İslam’ı şöyle ifade eder:

Manevi bir güneş de var, nevvar

O da İslam dinidir parlar,

Parlar afagı nura gerg eyler,

Hak-hakikat neyse hep söyler.

Fakat Şeyh Senan hak ve hakikatin Peygamberin memleketi Kabe'de de olmadığına inanmaktadır. Hakikat arşa çıkmıştır. Bu şikayeti önce kör Arap’ın türküsünde, biraz sonra da Şeyh Senan'ın yüksek sesle söylediği kendi ifadelerinde şifa bekleyen körlere yürek acısıyla aktardıklarında görmekteyiz.

Neyi görmek dilersiniz bilemem?
Yanıyor zulüm içinde hep alem,
Görmemek için bu çirkin işleri siz
Yalvarıp hakka hamdı şükür ediniz...

Bu şüpheler ve şikayetler Şeyh Senan'ı özel yaşantısında da rahatsız etmektedir. Kadınlara mesafeli duran Senan, güzeller güzeli Zehra'nın aşkını karşılıksız bırakmaktadır. Öte yandan uzaklarda yaşayan Humar'ın hasret ve gizli sevdasını çekmektedir. Humar'ın hayali ona hem neşe, hem izdırap yaşatmaktadır. Bu hayallerle kırk yaşındayken Tiflis'e gelir Senan. Onu ilk etkileyen doğanın güzelliği ve 
bölgenin iklimidir. Bu füsunkâr tabiat “yere indirilmiş cennet” gibi görünmektedir. Senan’ı ikinci etkileyense orada tanışmış olduğu deli Derviş ve onun sohbetleridir. Derviş, Senan'ın o güne kadar taşıdığı şüphelerin, hakikat arayışlarının canlı sembolü adeta heykeli gibi karşısında yücelmektedir. Derviş, imge olarak Senan'ın şüpheciliğinin zirve noktasıdır. Şeyh Senan, kendi varlı̆̆ını ve şüphelerini bu deli Dervişin simasında aynada ki gibi görmektedir. "Babam hayret, anam şüphe" diyen bu adam, daha ilk görüşten Senan'a idraksizliği idrak olarak bilen müritlerden, fanatik şeyhlerden daha sicak ve daha samimi gelmektedir. Senan “dinsiz olmakta bir tarikattır” fikrine kapılmaktadır. Eğer şuursuz, kör itikat inanç, iman sayılıyorsa, neden bilinçli itikatsızlık, akıl ve irade alameti tarikat sayılmasın? Dervişin sözlerindeki mantık ve felsefe, İslam'ı ve bütün dinleri inkâr etse de, Kur'an, İncil, Tevrat ve Zebur'u rivayet hesap etse de materyalizm ve ateizmden de uzaktır. Yalnız burada Derviş, şahsiyetin kudretini her şeyden üstün tutmaktadır. Belki de Senan'ı etkileyen de budur.

Hanımlardan uzak duran Senan burada Gürcü güzeli Humar'a rastlar. Bütün felaketin, bütün günahların sebebini kadınlarda gören ve onlardan uzak duran şeyh Senan, ilerleyen sahnelerde yerin, göklerin, yaşamın manasını Humar’ın aşkında bulur. Bu ona özgürce düşünmeyi, yaşam sevgisini, itikat kölesi olmadığını, ilk defa dünyalı olduğunu ve özgür bir insan olma hislerini kazandırır.

Şeyh Senan ateist değildir. Tarihten ve edebiyattan bize malum olan "vahdeti-vücut" panteizm anlayışına, biraz önce gördüğü dervişin tarikatsızlık felsefesine yakındır. Yazar, dönemin kahramanları gibi onu kaleme almak, onu suni biçimde ateist mevkiinde tutmak niyetinde olmamıştır. Piyesin yazıldığı ve sahnelendiği yıllarda idrak ve ahlaki önemi beynelmilel içeriği, dini eleştirel motifleri etkileyici olmuştur.

H. Cavid, kaleme aldığı "İblis" ve "Şeyh Senan" piyeslerindeki mevzuya yakın birçok eserler kaleme almıştır. Örneğin "Peygamber” eseri yukarıdaki eserlere zıt bir bakış açısı yansıtmakla din ve peygamber imgesini idol olarak aktarmıştır. Yazarın yaratıcılık döneminin sonlarına doğru kaleme aldığı "Kınyaz", "Seyavuş", "Hayyam”, "İblisin İntikamı” gibi piyeslerde de dini mevzulara az veya çok ölçüde eleştirel yaklaşım sergilenmiştir. Yalnız bunların arasında "Hayyam” eseri özellikle dikkat çekicidir.

Yazar, "Hayyam" piyesinde doğunun bu "panteist materyalist" filozofunu "azadem bütün küfr ile dinden” diyen şairin ve onun hayat yolunu dini idealizme, hurafe ve kör inanca karşı koymaktadır.

Uydunuz bunca hurafata yeter!

Bu hayat işte ölümden de beter.

El verir paslı, sönük adetler

Şen tabiat sizi azade diler.

Karışıp birleşin iffet de budur,

Şeyhin uydurduğu cennet de budur.

Hayyam'ın dili ile söylenen bu ifadeler, aynı zamanda H. Cavid'in kendi sesi, kendi vasiyeti olarak nitelendirilmektedir. Yazar kendisi de zıddiyetlerden geçmiş, yaşamın tüm zorluklarını görmüştür. Fakat yaşamı boyunca hayatı çatışmasız, adavet ve istismar olmadan; mutluluk, uyum içinde yaşamın olmasını arzulamıştır. Materyalistlere göre Cavid, din, hurafe ve tarikatları, soyut, hümanizm mevkiinden tenkit etmekteydi ki, yaşadığı bölgenin ve sistemin talebi başkaydı. Dini, "materyalizm ve ateizm" mevkiinden eleştirmesi talep edilmekteydi. 
The religious subjects that have reflections on literature and art and that have influential impacts on Azerbaijan national conscience / R. Mürseloğlu (pp. 206-219)

$\mathrm{Bu}$ anlamda Cafer Cabbarlı, dönemin ve sistemin beklentilerini eserlerine yansitan usta kalemlerindendir. Biz onun eserlerinde de dini motiflerin dikkat çekici biçimde aktarıldığını görmekteyiz. Örneğin, onun piyeslerindeki kahramanlar dünyada ki zorlukları, zulümleri görünce sik sık el açarak ulu Tanrı'dan imdat dilemektedir. Bu beklenti, bu umut, yazdığı eserlerindeki kahramanların, Aydın ve Oktay’ın kalbinde artık küskünlüğe ve inançsızlığa dönüşür. Aydın çektiği musibetlerin sebebini dünyadaki adaletsizlikte görse de diğer taraftan Tanrı'nın da adaletsiz olduğundan yakınmaktadır. Aydın sevgilisi Gültekin’in son nefesinde ellerini kaldırarak yüksek sesle: "Ey, ulu Tanri'm, aldiğın bu acımasızca intikam neyin karşılı̆ıdır, niçin? İstemem... nefret artık... her şeye nefret, bütün hayata, bütün varhğa nefret, sene de, varsan eğer!” Bu isyan, bu çlgınca itiraz kendini "sefiller kralı" ilan eden Oktay Eloğlu karakterine de has bir yaklaşımdır. O da kendi sevgilisi Firengiz öldürdükten sonra ellerini açarak: "Ey büyük sahip, söndür bu güneşi, ay ve yıldızları! Dünya karanlıktır bırak karanlk görünsün! Bırak bu şaşkın beşer, bir defa da olsa gerçeği görsün, görsün ki, o bir hiçtir. Sen kendin de bir hiçsin... yarattıklarında! Beceremiyorsan yaratma, yaratıyorsan yaşat!"

Aslında C. Cabbarlı kahramanları itikat meselesinde benzerlik bakımdan H. Cavid kahramanlarına yakındırlar. Bunların benzer yönlerini tespit etmek çok ta zor değildir. Yalnız Cabbarlı, tarihin, cemiyetin, sosyal kanunları ve bu kanunların kaynağından öte her hangi bir ilahi güç ve kudret olmadığına inanan ve Marksizmin "üst kurum" adlandırdı ̆̆ı bütün mefkure enstitüleri; siyaset, ahlak, hukuk, felsefe, ilim, sanat, aynı zamanda din de bu temeller üzerinde kaldığını öngören anlayış sahibidir. Ona göre din, hâkim sınıfa hizmet eden dolayısıyla mürteci mevkiinde olandır.

Cabbarlı'nın “Od Gelini” faciasındaki kahraman Elhan'ı mahpustayken kurtarmaya gelen, onu “kurtuluş ve saadete" davet eden, İslam savunucularından olan Akşin'e: "Bütün insan kasapları dünyayı bu şiarla çiğnemişler, 'kurtuluş ve saadet!' Onlar buraya yurdumuzun kan damarlarmı sormak, fakirlerin, güçsüzlerin, son lokmaların boğazından kesip Bağdat halifelerinin genelevlerine göndermek için gelmişler... Bu dinlerin hepsi güçlülerin mızrağın sallamak, güçsüzlerin iniltilerini, feryatlarm susturmak içindir. Benden öte bir Allah yoktur. Benim... yer yüzündeki hayat ve saadetlerin yaratıcısı. Benim... göklerin varhğındaki kuvvet ve iktidarın mahiyeti. Kadınları cansız şeylere çeviren, köle alışverişini, insan ticaretini doğrulayan Muhammetlere, güçsüzlerin kaderini güçlülerin merhametine havale eden Musalara, İsalara, yüz yirmi dört bin Allah tüccartna, metalarmı mızrak gücüyle satan Allah tellallarma, ben inanmiyorum. Onlarn sattıklar uydurma, yapma Allahlara ben inanmiyorum, inanmiyorum!".

Bu ifadelerden de anlaşılmaktadır ki, Cafer Cabbarlı oyun eserlerindeki din mevzusunu materyalizm ve ateizm açısından ifşa etmektedir. Yazar, diğer eserlerinde de aynı çizgide ve aynı üslupta eserler ortaya koymaktadır. Örneğin; "Sevil” ve "Almaz" eserlerinde kadın karakterleri materyalist-ateist bir felsefenin ürünüdür. "Sevil” eserinde Dilber karakterinde ki evli kadınla ilişki kurmak isteyen Ebdüleli Bey'e "Siz kendiniz halkı Müslümanhğa davet ediyorsunuz, peki şeriatta başkasının hanımına bakmak olur mu?” sorusunu soran Dilber'e Ebdüleli Bey "Şeriat sadece cahil insanlar içindir, fakir, garibanlar içindir, zevk ehline ve aydınlara ne şeriat?” diye cevap vermektedir.

"Almaz" piyesinde on sekiz yaşındaki genç kahramanın mücadele ettiği düşmanlar arasında molla Süphan ve Ocakkulu gibi din temsilcileri var. Her ne kadar yazar molla Sübhan'ı sahneye çıkarmasa da zina ve rüşvetle meşgul olduğu, kendinden yüksek makamlarda olanlara yaltaklık yapan biri olarak kaleme almaktadır. 
Din ifşası, özellikle Sovyet döneminde Azerbaycan edebiyatı ve sahne sanatının geleneklerinden sayılır. M. F. Ahundov, C. Memmedguluzâde, H. Cavid ve Cafer Cabbarlı ananelerinin en önemli devamcılarından biri de Samed Vurgun'dur. Onun "Vagif" piyesinde din ifşasına hususi yer verilmiştir. Eserin mevzusu farklı olsa da Azerbaycan halkının özgürlük mücadelesindeki kahramanların mutlaka din temsilcileriyle bir çatışma halinde oldukları çizgi eserde devam ettirilmektedir. Bu çatışmanın anlaşılır olması bakımından söz konusu eserdeki üç karakterin; Vagif, Vidadi ve Şeyh Ali’nin oyundaki yaşam çizgisi ve ilişkileri izlenmeye değerdir.

"Vagif" eserinin ilk perdesinde yazar, okuyucusunu bu iki şairle tanıştırmaktadır. Vidadi namazda ellerini açmış Allah'a yalvar:

Hudaya, insanın hali yamandır!

Neler çektiğimiz sana ayandır.

Manası varmıdır bin tarikatın?

Aç... Aç kapısını sen hakikatin.

Yazıktır dünyanın eşrefi insan

Büyüksün, adilsin, geç günahından...

Koma ki, yerlerde sürünsün beşer,

Dünyada kalmasın ne kötülük, ne şer.

İyilik insana bir sanat olsun,

Dünya boydan boya hep cennet olsun!

Vidadi, Allah'a, İslam’a ve ahirete inanmaktadır ve doğal olarak tüm ümitlerini Yaradan’a bağlamıştır. Vagif ise bu ihtiyar arkadaşından farklı olarak, ahiret dünyasına inanmamaktadır. Onun bütün ümitleri dünya ve insanlaradır.

Bırak nisye ardından şeyhler yürüsün,

O nisye cenneti bırak şeyhler görsün.

Boş sözdür "dünyayı hiçten yaradan"

Bütün cennetleri kuracak insan...

Kaydetmek gerekir ki, piyesin başlarında Vagif, İbrahim Han'a güvenmektedir. İbrahim Han'ı ikna ederek halkın geçiminin iyileştirmesini sağlayacağına inanmaktadır. Böylece Vidadi Allah'a, Vagif ise onun gölgesi Han’a inanmaktadır.

İlerleyen sahnelerde Han'la Vagif arasında kopukluk ve halkla Han'ı ayıran bir uçurum yaranması söz konusudur. Vagif'in halka ve halkın kahramanlarına olan sevgisi İbrahim Han'ın gazabına ve şüphesine sebep olur. Halkın gözüne ve aklına ışık tutmağa çalışan Vagif, Karabağ’’n şeyhi ve İbrahim Han'ın yakın danışmanı Şeyh Ali ile zıt bir tutum içindedirler. Vagifi "vatan haini” olarak nitelendiren Şeyh Ali ve dindaşlarına cevabında Vagif :

Ben değilim vatan haini,

Saydım nebilerin sonsuz sayını,

Bin yıldır baş eğdik, yalnız Kur'an'a,

Baktı gözlerimiz kör gibi ona. 
The religious subjects that have reflections on literature and art and that have influential impacts on Azerbaijan national conscience / R. Mürseloğlu (pp. 206-219)

S. Vurgun, Vagif ile Şeyh Ali simasında, onların münasebetlerinde ilim ile dinin, hatta sanat ile dinin kadim ve ebedi düşmanlı̆̆ını göstermiştir.

Sanatta ve edebiyatta özellikle Azerbaycan sahne sanatında dinin ifşası, Sovyet döneminin en önemli ve vazgeçilmez mevzularından sayılmaktadır. $\mathrm{Bu}$, bir taraftan dinin içtimai-tarihi kökleri ve dine münasebet meselesi ile, diğer taraftan güzel sanatın sosyal mahiyeti ve idrak kabiliyeti, bir başka yönü ise yeni neslin terbiyesi ve ateist tebligatın muasır vazifeleri ile ilişkili olmasından kaynaklanmaktadır.

Örnek verdiğimiz bütün bu eserlerden de anlaşılmaktadır ki, edebiyat ve sanata yansıtılan din mevzuları toplumun algılama biçimine, milli şuuruna etkili izlenimler bırakmıştır. Algılama sisteminde yedi şuur biçimi olduğu varsayımından bahsedilir. Sanat, din, ahlak, hukuk, ilim, felsefe, siyaset. Bütün bunlar iktisadi temeller üzerinde yapılanır ve toplumun varlı̆̆ını, sosyal ilişkilerle ve bu ilişkilerin çeşitli yönleriyle, çeşitli biçimlerde ifade eder. Bilinç biçiminin niceliği doğal ve öznel eylemlerden bağımlı olmayan bir zarurettir. Sanatın türlere ayrılması gibi şuurun da birçok biçimde ifade vasıtalarının olmasındaki sebep, sosyal yaşamın çok renkli, değişken ve haraketli olmasından kaynaklanmaktadır. Dolayısıyla algı ve bilinç süreci uzmanlaşmaya yönelir. Örneğin; ilim, doğanın ve toplumun kanunlarını, kaidelerini öğrenmekle meşgul olur ve elde ettiği bilgiyle soyutluğu tefekkürde biçimlendirir. Yaşamın ve insan tefekkürünün genel kaideleri, sistemli ve sentezli biçimde felsefede ifadesini bulur. İnsanların biri biriyle ve birey olarak toplumla olan ilişkileri, ailede ve şahsi yaşamlarındaki sosyal ilişkileri, davranışları, ahlak anlayışına dahildir. Hukuk, hakim toplumun iradesini onun çıkarlarına uygun kanunlarda beyan eder, mecburiyet ve hakimiyet gücüne onlara riayet edilmesini gözetler. Devletin kurgusunu, onun faaliyetini, iç ve dış güçlerle ilişkilerini, iş akışını, onun başka devletler ve milletlerle ilişkilerini siyasi şuur ifade eder. Din doğanın ve toplumsal güçlerin mistik tasvirinin (aslını ve tahrif olunmuş) şerhini verir. Nihayet Sanat, şuurun ve insan faaliyetinin kendine has niteliksel biçimidir. Dünyanın somut ve hissi idrakine, estetik biçimde benimsenmesine hizmet eder.

Bu bakımdan şuurun farklı ifade biçimleriyle sanatın ilişkilerini gözden geçirmek hem zaruri hem de ilginç olacaktır. Özellikle dünya coğrafyasındaki dini mevzuların sanat ve edebiyat üzerinden tartışlır biçimde aktarılması, topluma yön verme açısından sanata etkin bir rol kazandırmaktadır. Halkının çoğunluğunun Müslüman inanca sahip olduğu Azerbaycan, sosyal ve siyasi sistemin ürettiği din mevzularından hangi ölçüde etkilendiği dolayısıyla bu etkileşimin sanata ve edebiyata nasıl yansıtıldığı günümüzde de tartışlır ehemmiyet kesp etmektedir.

\section{Sonuç}

Sanat ve din, tarih boyu izledikleri yol ve maksatlarına göre birbirine zıttır ve karşı karşıya gelmiştir. Din, sanatı ya kendi hükmüne almayı ve sanatın gücünü tebligat aracı olarak kullanmayı düşünmüş ya da estetik yaratıcılığı gereksiz, dünyanın heves ve hazzının eğlencesi olarak lüzumsuz olduğunu ileri sürerek "günah", "haram" "şeytan ameli" diyerek yasak olduğunu öne sürmüştür.

Sanat da kendi gücünü dine karşı acımasız biçimde kullanarak dini, aydınlanma ve gelişmenin önündeki en büyük engel olarak gösterme eylemi içinde olmuştur. Özellikle özgürlük akımının güçlendiği dönemlerde din, sanatın hedefi haline gelmiştir.

Makalemize konu edilen eserlerden de anlaşılmaktadır ki muhtelif dönemlerde "din mevzusu" toplum inançlarını sorgulama ve algılama bakımından etkili olmuş, milli şuurun gelişmesine, sosyolojik ve 
siyasi açıdan tesirini göstermiştir. Bu farklılıklar ışı̆̆ında baktığımızda her iki tarafın görüşleri toplumun tefekkür biçimini, dünyayı algılama ve bakma biçiminde etkili olmuştur. Çalışma içinde verilen farklı örneklere bakıldığında, sanatçının yazdığı dönemin koşullarından nasıl etkilendiği ve bunu nasıl yansıttığını da görmekteyiz. Bu dönemleri iyi anlamak ortaya çıkan çalışmaların mantığını anlamak için önemli bir husustur.

Beşeriyet tarih boyu dine, Allah’a inanan ve şüphe eden ateizme kadar büyük bir yol kat etmiştir. Bu yolda her iki unsur bir birinden istifade etmiş, toplumun gelişiminde sanat ve din, önemli ve tarihi rol üstlenmiştir.

\section{Kaynakça}

Ahundov, M. F. (1951). Eserleri. II. Cilt. Bakü : Azerneşr

Babayev, N. \& Nerimanov, R.(1998). Berde Tarihin Aynasinda. Bakü: Elm ve Heyat Neşr.

Bünyadov, Z. \& Yusifov,Y, B. (1996). Azerbaycan Tarihi. Bakü: Elm Neşr.

Cabbarlı, C. (2005). Eserleri, Muasır Azerb. Edebiyatı I-II-III-IV cilt, Bakü: Lider Neşriyat.

Cavid,H. (2005). Eserleri, beş ciltte, II. Cilt. Bakü : Lider Neşriyat.

Erhat, A. (2011). Mitoloji Sözlüğü. İstanbul: Remzi Kitabevi

Geybullayev, G. (1994). Azerbaycan Türklerinin Teşekkülü Tarihinden. Bakü: Azerbaycan Devlet Neşriyatı.

Göl, H. (2016). Geçmişten Günümüze Azerbaycan. Bitlis Ünv. Sos. Bil. Enst. Dergisi, cilt V, sayı 1.

Hüseyinov, F. (1986). Molla Nesreddin ve Molla Nesreddinciler Bakü: Yazıcı Neşriyat.

İsmayıl, M. (1997). Azerbaycan Tarihi, Bakü. Azerneşr.

Kazımov, G. (2009). Azerbaycan Dilinin Tarihi, Bakü. Azerneşr.

Marks, K. \& Engels, F. (1951). 2, t. 2,s, 469. Moskova: soç.izd.

Marks, K. \& Engels, F. (1951). Ob iskusstve, t. 2, s, 53. Moskova: soç. izd.

Marks, K. \& Engels, F. (1951)..2, t.2. s, 144. Moskova: soç. izd.

Memedov, M. (1971) İncesenet ve Din. Bakü: Gençlik.

Memmedguluzade, C. (2004). Eserleri 4 ciltte, Önder, C. I. Bakü.: Azerneşr.

Memmedova, D. (2007). Azerbaycan Dramaturgiyası Antologiyası dört ciltte, I. cilt. Bakü: Şerq-Qerb.

Mürselov, C. (2016). Azerbaycan Dini İnançlarına Genel Bir Bakış. Bingöl Ünv. İlahiyat Fak.Dergisi, cilt IV, sayı 8

Sabir, M.E. (2002). Hophopname. Bakü: “Turan” Neşrler evi.

Vurgun, S. (2005). Seçilmiş Eserleri, II. Cilt. Bakü: Şark Garp. 